\title{
Local Political Dynamics: Bugis Ethnic Perception of the Urgency of Decentralization Politics in Indonesia
}

\author{
Andi Yakub ${ }^{1}$, Jamaruddin Suro ${ }^{2}$ \\ \{andyakub@gmail.com ${ }^{1}$,jamaruddin.s@gmail.com ${ }^{2}$ \} \\ Department of Political Science, Hasanuddin University, Jl. Perintis Kemerdekaan \\ KM 10, Makassar ${ }^{1}$ \\ Government Regency of Takalar, J1. Jenderal Sudirman No. 26, Takalar, Indonesia ${ }^{2}$
}

\begin{abstract}
Indonesia is a country inhabited by hundreds of ethnic groups with different geographical, natural, social and cultural conditions. The decentralization and autonomy of the region in Indonesia is an acknowledgment of the diversity of ethnic groups to form unity (bhineka tunggal $I \mathrm{ka}$ ), and create social harmony and development of order to maintain national stability through empowerment of local people by building roads from the outskirts. This article will discuss the importance of decentralized politics and regional autonomy in Indonesia with the approach of the Bugis ethnic perception towards decentralized political urgency and regional autonomy policy. The results of the study found that the majority of the Bugis ethnicity is more reviosyncratic than conservative or orthodox and pragmatic. Reviosionist means that the Bugis ethnicity in decentralization of power and authority over the region can still be carried out with respect to local values and local wisdom. Nevertheless, a change in the decentralized political model based on the values of local justice can be carried out gradually with the spirit of Nation unity and mutual development for the well-being of the people.
\end{abstract}

Keywords: Decentralization;Bhineka Tunggal Ika;Social Harmony, National Stability, Local Politic

\section{Introduction}

Decentralized to create social justice for the local people.

\section{Research Method}

This study is contextual using qualitative methods that emphasize the meaning (verstehem) of the phenomena of human interaction in certain situations. Therefore, the emphasis on the human element as an instrument of study becomes very important. Qualitative methodology is in the naturalistic viewpoint and strong in interpretative understanding of human experience. At the same time, this study is characterized by politics and is formed from a variety of ethical and political views.

From this view, the type of study used is a phenomenological perspective. Following the phenomenological perspective of a science is not purely empirical, but it includes phenomena 
such as perception, idea, willingness and beliefs about something outside the subject. Phenomenology demands a holistic approach, looking its object naturally and developing idiographic science[1] by the method of triangulating data collection[2].

\section{Result and Disscussion}

\subsection{The Urgency of Political Decentralization and Regional Autonomy}

Generally, urgency of political decentralization can be differentiated based on the researcher's point of view. Some of researchers perceived it from political, economic, macromicro, and even socio-culture development perspectives.

Political decentralization in terms of economical dimension is to amplify the ability of local government in providing public good and services, as well as enhancing the efficiency and effectiveness of economic development in a region [3]. This view implies that political decentralization functioned as an instrument to widen public space for people who make choices on public goods and services where would eventually towards contribute existence of balancing between individual rights and collective harmony. Political decentralization where consequent will necessarily release regional autonomy necessity as it will increase people political participation in turn to support development of social, economy and political aspects [4].

Thus, mentioned that there are six main aspects related to principal value of political decentralization urgency [5]. Those are: (i) Trust towards equality and justice, (ii) Trust towards consultation and dialogue, (iii) Importance of adaptation and toleration, (iv) Participation in unity in diversity, (v) Empathy, which is love and generosity, commitment towards freedom and peace, and (vi) Changes without violence.

Moreover political decentralization from macro aspect or the aspect of importance central government has three urgency's which are: (i) Political education, (ii) Leadership training, and (iii) Forming of political stability. In micro or regional importance, those three urgencies are: (i) Political decentralization, ii) Local government's responsibility towards the people, and (iii) Response from the local government towards various concerns [6]. The politics of decentralization and regional autonomy, in terms of social development is an effort to enhance human capacity to influence its future ", with the main implications of social development: capacity, justice, empowerment, sustainability, freedom and independence.

The increasing attention to political decentralization and administrative decentralization is not only a symbol of the perceived weaknesses of centralized administration planning, but also a shift in policy that emphasizes growth strategies that should be accompanied by strategic planning. In addition, it is generally acknowledged that development is a complex and uncertain process, which cannot be easily planned and controlled from the center. The politics of decentralization and full autonomy of the region that were extinguished by the central government were impossible. However, by looking at the opinions of Indonesian founders, there are (subtantive) ideas in decentralized political concepts and regional autonomy reflected in the views and consensus of Soekarno, Muhammad Hatta, Muhammad Yamin, and Soepomo on the need for decentralization and regional autonomy. Mohammad Hatta's statements, present ideas on decentralized politics and regional autonomy such as: "Providing regional autonomy does not mean implementation of democracy, but encouraging the growth of auto-activiteit. Autoactiviteit means moving alone, self-executing what is deemed important within one's 
surrounding. With the growth of auto-activiteit, what is meant by democracy will be achieved that is governing by the people and for the people. The people not only determine their destiny, but improve their destiny" [7].

The content of speech, proposal, and debate of Indonesian founding fathers emphasize that they were viewing political decentralization in Indonesia as a fundament that could be accepted. In the end, they concluded that a decentralized united nation system is the most suitable state system for people of Indonesia that are diverse in terms of geography, tribe, religion, ethnicity, and groups (political, economic and cultural interests).

The different thoughts mentioned concluded that a more decentralized autonomy system benefits in terms of (i) wider chance of equal distribution of power among local communities, (ii) better inclusiveness of society's political education, (iii) stronger stability of political system, and (iv) closencess of the nation to its people.

\subsection{The Perceptions of the Bugis Elite on decentralized political urgency in South Sulawesi}

Perceptions are what are known through facts, representations, figures, examples and more. perception without concept is empty, and concept without perception is blindness, Immanuel Kant in[8]. Theoretically, perceptions can be categorized into four patterns. First, the oppositionist is a group of elite actors who want a fast, radical and fundamental political change in decentralized political models and regional autonomy [9]. Second, revisionists, a group of local elite actors believe that model change needs to be done gradually to avoid turmoil that can endanger political stability and political life. Third, conservative or orthodox, a group of local elite actors who oppose any change in decentralized political models and regional autonomy towards competitive democracy. Fourth, pragmatic, a group of local elite actors do not care as long as their political economic interests remain.

This article discusses how the Bugis ethnic perception of decentralized political urgency in the concept of Bhineka Tunggal Ika, establishing national stability in the concept of Central and Regional relations, and the concept of decentralized political meaning, Build from the fringes: From region to Indonesia.

Issues regarding the domination of Jakarta as central power and regional's centre of economic activity still remains as a fundamental reasoning that are faced by the regions. The issues mentioned will offend the discussion of urgency of political decentralization and regional autonomy policy in Indonesia.

In developing countries, dilemma regarding centralization and decentralization is a prominent issue particularly related to efficient utilization of limited natural resources. Centralization and decentralization leads to introduction of excavation of natural resources and returned distribution and allocation of natural resources and extractive capability. The phenomenon in which a region that is rich with natural resources and contributed more gain the lowest allocation of economic asset causes raises discontentment. Eventually, separatism movement erupted such as Gerakan Aceh Merdeka (GAM) or Organisasi Papua Merdeka $(O P M)$.

In Indonesia itself, discourse about decentralization and regional autonomy becomes prominent when the execution of economic development that is implemented by new order regime encounter problems, that causes formation of structure inequality between sectors or between regions. The occurrence of the inequality pattern in the future could be a strong back wash in order to continue the development of nation. 
Besides, re-emergence of political decentralization and regional autonomy policy means that the central government cannot escape from reduction of fund whether from crude oil or foreign revenue (export products). The reduction of crude oil income and foreign revenue causes the shifting in the structure of state revenue as well as increase in tax revenue as a force and stabilizer of economic growth. This tendency has been happening throughout the years within the government whether in central Jakarta or local government outside of Java Island. Autonomy is perceived solely from economic perception that is in terms of its efficiency and effectivity. At the same time, there is "phobia" towards past political decentralization without observing democratization and political dynamic aspects of the local community and regional government that would occur. This might be due to the strong effect of planned paradigm development that has central characteristic (top down) until the central government believes that they are fully responsible towards national development. In terms of finance, it is clear the region is at the end position and is very dependent while dynamic regional development is difficult to be performed without sufficient fund (presence of fiscal decentralization). Local government becomes slow in handling problems that arise in their region such as poverty, citycountry inequality, and small locally-generated revenue as they are ripped of all attributes of regional autonomy in Indonesia as political decentralization.

Hence, in order to create economic justice or economic democracy stated that ethical rules of games must be obeyed in economic relationship [10]. In regards to relationship of central and regional, economic justice must become the moral foundation in which the central government must make effort to understand and fulfil it. Strengthening of regional economic structure that is based on local wisdom; Bugis community is known for the concept mutual cooperation/helping each other and national economic system that is not too centralistic. This clearly will lift up the region to be more active and independent without depending on central in the form of "cooperation" which means economic democracy. Economic democracy will exist by expanding decentralization and regional autonomy. Regions that have high potential must quickly achieve independent in organizing regional finance (fiscal decentralization) so that economic, politic and social gap can be overcome at its own region as well as reducing poverty and dependency towards central with the designation of development from outskirts: from region to Indonesia, with the framework to create social justice for local community.

Interviews with "SM" indicate that the process of delegating authority in the context of decentralization, on the whole is not significant because it is not followed by regional financial balance reforms that give the region more time to manage its financial potential due to large centralized revenue sources, while the smaller ones are allocated to the regions. Regional autonomy is a political dynamic, in which the local government is empowered to decide what is best for the people of South Sulawesi and centralization is defined as political stagnation. They blamed centralism for the fact that according to the Bugis elite that South Sulawesi was rich in natural resources but the people were still poor, this was supported by BPS poverty data that the number of poor people increased from 787,670 people (2013) to 864,300 people (2014) and 864,510 people in 2015[11].

Some criticisms of local elites such as an interview with "AA", Bugis regional cultural observer, say that Jakarta is not sensitive to local needs, the central government (Jakarta) is too afraid of regional autonomy that will result in disintegration, as has been the case in South Sulawesi in the past. This criticism is supported by a "Mul" (Bugis culture researcher) interview that considers authoritarianism and oligarchy as the cause of centralization of power. Therefore, it is inevitable that we have a centralized government, these systems work together. The result is clear that the central domination of every aspect of people's lives in the region. 
Meanwhile, an interview with "AH" Manager of Islamic Shariah Enforcement Preparation Committee (KPPSI) said that the central government was involved only in security, monetary, and international relations, the rest of which had to be taken care of by the local government. Thus, central and regional relations would be more equitable, if the concept of federation was unacceptable. Governance systems with the united states control local authority and life more strictly than the federal system[12]. Contrary to the perception of local politicians "AN" members of the PPP DPRD Frakri say that autonomy should be evaluated as each district has different characteristics and natural resources, for example Jeneponto and Makassar districts have different natural resources and regional income. This means that the central government must protect the interests of weak areas from natural resources and income.

Therefore, the power to first be granted to the Regency is not in the Province. The province plays the role of coordinator but does not directly govern the district, because of real problems or community activities at the district level. Therefore, the power given at the State level is a form of re-centralization. I do not think we would like to repeat these misunderstandings[13].

However, it is slightly different from the perception of the "AMR head of Galung village" of Soppeng South Sulawesi. He said that the autonomy of the area is now good. The idea of decentralized politics and regional autonomy would greatly disrupt unity and unity, if the region demanded greater autonomy from the center. For all this time, we have enjoyed the development of electricity such as the lighting of the village. Therefore, the present system of government must be maintained because decentralized ideas and regional autonomy are largely inadequate with the spirit of unity.

However, an explicit view emphasizes that decentralized policing and regional autonomy do not necessarily change the state of the united states into a federal state. In an interview with the local political elite "AFP" / Regent Bone said "Larger autonomy should not make Indonesia a divided nation in any sense." Although, we are promoting decentralization or greater autonomy but must maintain the country unity. "Therefore, decentralization must occur gradually, not at the expense of unity for decentralized politics and regional autonomous police for whatever reason.

The "AP" cultural leaders say that the political agenda / motivation of regional decentralization and autonomy is: first, limiting the power of the central government to avoid absolute power and tend to be despotic, thus necessitating a (centripetal) distribution of power / governance evenly from region to village. Second, economic growth is fair and equitable to the village. Third, the function of government management is to serve the people throughout Indonesia to the maximum.

Intellectuals "ST" (Hasanuddin University lecturer) explains that decentralization of regional politics and regional autonomy has been effective in Indonesia since January 1, 2001, providing valuable learning processes, especially in the life of democracy, togetherness, justice, and regional diversity in unity through the support of the government to grow and develop early initiatives (districts and communities) towards community well-being. The basic principles of decentralized politics and regional autonomy are conceptualized implementation of regional governance: delegation of authority, revenue sharing, power, diversity in unity, local independence, regional capacity development.

The second view is represented by those who are more sympathetic to federalism without explicitly supporting the transition from the union system to the federal system. The unity system is not a bad idea as long as there is a fundamental freedom given to the region to implement local government based on their own concepts. Local expressions will have the opportunity to be expressed without fear of interfering with national unity and within the united 
states still allow for community pluralsime, as long as there is autonomy in the region [14]. (interview with local political elite "TAY": Vice Regent of Bulukumba).

From some responses, it was generally agreed that autonomy should be taken in the broadest sense, so that local affairs could be freed from the interference of other institutions. The central government will only be involved in defense and national security, monetary and international relations. This version of autonomy is very similar to a state-based federation and its supporters are considered federalists.

Although not all Bugis elites explain the level of autonomy they must give, some of them point out that the level of district government should be given greater priority than the provincial level. Their views are revisionist, because they focus on the real problem areas. At the district level, the implementation of governance and decision making directly interact with the community. They propose that the provincial government perform the functions of a coordinator, not regulate districts like the "orde baru". The reason for decentralization is being directed to the district because it covers relatively small regions and populations, so the problem of separatism is unlikely. Separatism has always been feared by the central government as a potential threat to the region

However, not all Bugis elites were enthusiastic about the larger decentralized political ideas of the region. A small part of the Bugis elite opposed these ideas. They think that decentralized politics will create problems rather than solve problems and undermine the spirit of national unity. According to them the feeling of being a large Indonesian family represented in the idea of unity and unity is threatened. The second hand, decentralized politics goes against the spirit of national unity in the United States of the Republic of Indonesia (NKRI), the jargon NKRI is a fixed price.

\section{Conclusion}

Interviews of various Bugis elites of formal and informal elites indicate that their perceptions differ from decentralized political urgency and regional autonomy policies conducted in Indonesia, especially in South Sulawesi. For formal local elites, politicians and bureaucrats support decentralization and regional autonomy, but there needs to be a balance of power and authority between central and regional, provincial and district, while non-formal local elites are increasingly looking at regional (centrifetal) power, not the central government (Jakarta) is centrifugal, so the region's natural resources can be managed including its finances by remaining a united state and appreciating ethnic diversity.

Therefore, among Bugis elite actors there is a difference in perception in responding to the discourse of political reform, especially decentralized politics and regional autonomous police in South Sulawesi, it can be concluded that: most of the local Bugis elites have a reviosionist response to the gradual change to decentralized model and regional autonomy. Large and broad authority should be given to the region gradually to accelerate the well-being of the community based on local values and local wisdom. While only a small part of the Bugis elite whose ideology was conservative or orthodox.

Conservative/orthodox Bugis elites prefer national stability to maintain unity in diversity, so they view existing decentralization as good enough to govern people's lives. Pragmatic local elites only care about their particular economic interests, they do not care how decentralized and autonomous the regional government gives the region.

Urgency of political decentralization and regional autonomy is hoped to create: (i) efficiency and effectiveness of government management that leads to public harmony, (ii) regional 
administration that is responsible in various aspects of local community's life, (iii) local government that is responsive towards various issues that are encountered by local community, and (iv) an increase role of community in democracy administration process as in there is an opening for the people to participate in various political activities at the local level. Therefore, political decentralization must be able to enhance the welfare and quality of life of the local community: First, maintain Bhineka Tunggal Ika. Second, protect national stability and third, strengthen local community based on local wisdom and local values, and move forward towards the policy of development from outskirts: from region to Indonesia, with the framework to create social justice for local community.

\section{References}

[1] Muhajir, N.: Metodologi Penelitian Kualitatif. Yogyakarta: Penerbit Rake Sarasin. (1996)

[2] Creswell, J. W. Research Desing: Pendekatan Metode Kualitatif, Kuantitatif, Dan Campuran. Yogyakarta: Pustaka Pelajar (2018)

[3] Rondinelli, D.A., and Cheema, G.S. (eds,).: Decentralization and Development: PolicyImplementation in Developing Countries. Beverly Hilss: Sage Publication (1983)

[4] Ruland, Jurgen.: Urban Developmen in Souteast Asia: Regional Cities and Local Government. Boulder: Westview Press 4 . (1992)

[5] Kymlicka, W.: Kewargaan Multikultural. Jakarta: LP3ES (2002)

[6] Bryant, C. W., \& Louise, G.: Manajemen Pembangunan Untuk Negara Berkembang. Jakarta: LP3ES (1989)

[7] Hoessein, B.: "Otonomi Daerah Dalam Negara Kesatuan Sebagai Tanggapan terhadap aspirasi Kemajemukan Masyarakat dan Tantangan Globalisasi”. Usahawan. 04/ April. Jakarta. 7, (2001)

[8] Roskin, M. G., Robert L. C., Medeiros, J.A., Jones, W. S. Pengantar Ilmu Politik. Jakarta: Kencana 8, 18 (2016)

[9] Sparinga, D.: Discourse, Democracy, and Intelectuals in New Order. (A PhD. Thesis,Flinders University) 9 (1997)

[10] Mubyarto. Sistem dan Moral Ekonomi Pancasila. Bandung: LP3ES (1988)

[11] Badan Pusat Statistik (BPS). Indikator Makro Sosial Ekonomi Sulawesi Selatan. Triwulan I. Press (2017)

[12] Roskin, M. G., Robert L. C., Medeiros, J.A., Jones, W. S. Pengantar Ilmu Politik. Jakarta: Kencana (2016)

[13] interview with local political elite: "AFP": Regent Bone

[14] interview with local political elite "TAY": Vice Regent of Bulukumba 